\title{
PEMBINGKAIAN PESAN DAN PERSEPSI RISIKO PSIKOLOGIS PADA ISU KONSUMEN HIJAU
}

\author{
Euis Soliha (zulfa_arkan@yahoo.com) \\ H. Sophiyanto Wuryan \\ R. Basiya \\ Program Pascasarjana Universitas Stikubank
}

\begin{abstract}
The purpose of this research is to analyze the effect of the message framing on the perceived psychological risk on green environmental issues. Consumers nowadays have become more critical about issues on green consumer due to the increasing levels of consumers' knowledge. Government and marketers also should perform active movement to increase consumers' awareness of their environment. Those include giving a message to the consumers. When marketers deliver the message, they need to concern about message framing. Message framing is likely to influence the consumer's perception. Research design used in this study is design experiments. In this case the message was manipulated by message framing: positive and negative. The hypothesis of this study, $\mathrm{Hl}$ : There are differences in perceived psychological risk perception on advertising by using positive and negative message framing, H2: There are differences in perceived psychological risk of consumers on advertising by using positive and negative framing that is reinforced with consumer knowledge. The analysis results of hypothesis 1 showed that there are significant differences in perceived psychological risk on advertising by using positive and negative message framing. Consumers feel that perceived psychological risk is lower in the ad with a positive message framing. Therefore, on advertising products related to green consumer issues, using positive message framing will be more effective. The analysis result of hypothesis 2 showed that there are no significant difference in perceived psychological risk on advertising by using positive and negative message framing that is reinforced by consumer knowledge. Consumer knowledge did not moderate the effect of message framing on perceived psychological risk.
\end{abstract}

Keywords: message framing, perceived psychological risk, green consumer, consumer product knowledge

\section{PENDAHULUAN}

Dalam pemasaran dan periklanan, pemasar sering menghadapi kesulitan mengungkapkan pesan. Pesan dapat diungkapkan dalam pembingkaian positif atau negatif. Riset juga mengindikasikan bahwa pengaruh pesan tidak sama pada semua kondisi dan dapat dimoderasi oleh faktor-faktor lain. Ketika orang berharap pesan berbingkai negatif, pesan berbingkai positif akan diterima lebih teliti karena pesan berbingkai positif akan menimbulkan konflik dengan harapan individu. Beberapa penelitian mengenai pembingkaian pesan masih menunjukkan hal yang bertentangan.

Penelitian Buda dan Zhang (2000) menunjukkan terdapat perbedaan yang signifikan pada pembingkaian pesan. Subjek yang menerima pembingkaian pesan positif mempunyai tingkat sikap terhadap produk yang lebih besar secara signifikan daripada subjek yang menerima pembingkaian pesan negatif. Levin dan Gaeth (1988) menunjukkan bahwa pembingkaian positif lebih unggul daripada pembingkaian negatif, demikian pula Smith (1996) menyimpulkan pendapat yang sama. Secara berlawanan beberapa penelitian menunjukkan bahwa pembingkaian pesan negatif lebih efektif daripada pembingkaian pesan positif seperti penelitian Ganzah dan Karsahi (1995) serta penelitian Meyerowitz dan Chaiken (1987). Rothman dan Salovey (1997) menunjukkan bahwa pembingkaian pesan 


\section{Euis Soliha}

\section{H. Sophiyanto Wuryan \\ R. Basiya}

negatif lebih efektif dalam mempengaruhi kognisi dan perilaku untuk perilaku pendeteksian, sedangkan pembingkaian pesan positif lebih mempengaruhi perilaku pencegahan. Maheswaran dan Levy (1990) menunjukkan bahwa pembingkaian negatif lebih efektif dalam mempengaruhi sikap terhadap pengujian kolesterol pada subjek dengan keterlibatan tinggi, sedangkan pembingkaian positif lebih efektif untuk subjek dengan keterlibatan rendah.

Isu konsumen hijau saat ini menjadi perhatian utama konsumen. Konsumen akan meninggalkan produk ataupun jasa yang tidak ramah lingkungan dan mereka akan beralih pada produk ataupun jasa yang ramah lingkungan. Pemasar dalam hal ini perlu menginformasikan bahwa produk ataupun jasa yang diproduksinya adalah ramah lingkungan. Informasi yang disampaikan oleh pemasar ini biasanya dikemas dalam sebuah iklan. Salah satu tujuan iklan adalah untuk memberi informasi kepada konsumen. Terkait dengan pesan yang disampaikan ini, pemasar dapat memutuskan apakah pesan akan dibingkai dalam pembingkaian positif ataukah negatif.

Adapun permasalahan dalam penelitian ini terkait dengan manakah yang lebih efektif untuk iklan konsumen hijau apakah iklan dengan pembingkaian positif ataukah negatif.

\section{LANDASAN TEORI DAN PENGEMBANGAN HIPOTESIS}

\section{Periklanan}

Periklanan adalah segala bentuk penyajian dan promosi ide, barang atau jasa secara nonpersonal oleh suatu sponsor tertentu (Kotler dan Keller, 2009: 512). Dengan demikian iklan dimaksudkan untuk menginformasikan, membujuk, atau mengingatkan. Untuk dapat mencapai tujuan tersebut, maka iklan harus dikemas dengan baik agar konsumen memberikan respon seperti yang kita harapkan. Periklanan merupakan hal penting yang harus dilakukan oleh perusahaan. Faktor pentingnya adalah bagaimana mengiklankan produk/jasa secara berbeda dan unik. Iklan yang tampil beda dan membawa pesan yang berbeda pula lebih cepat diterima maknanya oleh konsumen, sehingga konsumen lebih cepat dalam menangkap pesan, produk/jasa dan merek yang diiklankan.

Iklan merupakan komunikasi searah dari produsen kepada konsumen. Komunikasi yang efektif melibatkan: (1) sender, (2) encoding, (3) message, (4) media, (5) decoding, (6) receiver, (7) response, (8) feed back, dan (9) noise (Kotler dan Keller, 2009: 514-515). Sender/Source adalah pusat yang mengidentifikasikan sasaran dan mengembangkan tujuan komunikasi. Encoding adalah proses penterjemahan informasi atau tujuan komunikasi menjadi suatu pesan yang akan disampaikan kepada penerima pesan. Message adalah pesan yang akan disampaikan. Media meliputi pemilihan terhadap media yang akan digunakan untuk menyampaikan pesan. Decoding adalah proses pemahaman atau proses penterjemahan kembali pesan yang diterima melalui media tersebut ke dalam tujuan komunikasi dan disimpan dalam memori penerima pesan. Receiver adalah siapa penerima pesan. Response adalah tanggapan dari penerima pesan. Feed back adalah evaluasi terhadap efektifitas komunikasi.

\section{Persepsi Risiko Konsumen}

Konsep persepsi risiko berhubungan dengan sejumlah risiko atas pembelian suatu produk atau jasa (Cox dan Rich, 1964; Dowling dan Staelin, 1994). Oleh karena itu, semakin tinggi harga produk dan produk dengan semakin tinggi keterlibatan konsumen maka akan semakin tinggi persepsi risiko konsumen.

Jacoby dan Kaplan (1972) dalam Friedman dan Friedman (1979) menyebutkan lima tipe risiko yang dipersepsikan, yaitu risiko keuangan, risiko kinerja, risiko fisik, risiko psikologis, dan risiko sosial. Risiko kinerja adalah risiko yang dihubungkan dengan ketidakpastian mengenai 


\section{Jurnal Manajemen Teori dan Terapan}

Tahun 6. No. 2, Agustus 2013

produk yang kinerjanya tidak sesuai dengan yang diharapkan. Risiko keuangan adalah suatu risiko yang berhubungan dengan semua biaya dan pengeluaran untuk memperoleh produk dan menghadapi ketidakpastian tentang produk. Risiko tersebut dinilai dengan sejumlah uang (Grewal, et al., 1994).

Risiko sosial adalah kemungkinan penggunaan produk akan mempengaruhi cara berpikir orang terhadap dirinya. Risiko psikologis adalah kemungkinan produk tidak sesuai dengan citra diri konsumen. Risiko fisik adalah kemungkinan produk akan berbahaya untuk pengguna (Jacoby dan Kaplan, 1972 seperti dikutip Friedman dan Friedman, 1979).

\section{Hubungan Pembingkaian pesan dan Persepsi Risiko Konsumen}

Pengaruh pembingkaian pesan dapat dipahami dari perspektif yang ditawarkan peneliti dalam proses informasi. Literatur proses informasi fokus pada proses kognitif yang mana konsumen menyatukan bermacam tipe informasi. Dalam pemasaran dan periklanan pemasar sering menghadapi kesulitan mengungkapkan pesan dalam pembingkaian positif atau negatif. Sebagai contoh, pembingkaian positif adalah "85 persen tingkat kepuasan," sedangkan pembingkaian negatif adalah "15 persen tingkat ketidakpuasan." Riset juga mengindikasikan bahwa pengaruh pesan tidak sama pada semua kondisi dan dapat dimoderasi oleh faktor-faktor lain.

The Elaboration Likelihood Model (ELM) menjelaskan bahwa variabel-variabel dapat berpengaruh dalam meyakinkan atau membujuk dengan sejumlah cara. Variabel-variabel ini dapat sebagai isyarat yang sifatnya kurang penting dalam meyakinkan atau membujuk atau dapat berpengaruh memperluas atau mengarahkan elaborasi pesan (Petty dan Cacioppo, 1986 dalam Buda dan Zhang, 2000). Model ELM menunjukkan cara bagaimana konsumen memproses informasi dalam kondisi keterlibatan tinggi dan keterlibatan rendah. Model ini memberi rangkaian kesatuan mulai dari pemrosesan informasi yang sentral sampai pada pemrosesan informasi yang bersifat tambahan/pelengkap atau bukan hal yang sentral. Hal yang bersifat sentral dalam istilah Petty dan Cacioppo adalah elaborasi dan halhal yang bersifat tambahan/bukan sentral disebut sebagai bukan elaborasi. Konsumen yang mempunyai keterlibatan tinggi terhadap suatu produk akan memfokuskan pemrosesan informasi (iklan) pada hal-hal yang sentral dan detilnya. Sementara konsumen yang mempunyai keterlibatan rendah akan lebih memperhatikan informasi (iklan) pada unsurunsur yang bukan sentral dari iklannya.

Ketika orang berharap pesan berbingkai negatif, pesan berbingkai positif akan diterima lebih teliti karena pesan berbingkai positif akan menimbulkan konflik dengan harapan individu. Harapan pembingkaian pesan dalam periklanan pada umumnya positif, tetapi dalam suatu hal diketahui negatif, misalkan iklan kesehatan. Dalam iklan kesehatan, konsumen biasanya ingin mengetahui apa bahaya atau akibat kalau seseorang tidak mengonsumsi makanan tertentu atau tidak melakukan hal-hal tertentu.

Pembingkaian pesan positif didefinisikan sebagai komunikasi yang menekankan keunggulan merek atau keuntungan potensial konsumen dalam suatu situasi. Sementara pembingkaian pesan negatif didefinisikan sebagai komunikasi yang menunjukkan ketidakunggulan merek atau kerugian potensial konsumen dalam suatu situasi (Grewal, et al., 1994). Harga berpengaruh pada persepsi risiko kinerja yang semakin besar ketika pesan dalam berbingkai negatif dan harga berpengaruh pada persepsi risiko keuangan yang semakin besar ketika pesan berbingkai positif (Grewal, et al., 1994).

Penelitian Buda dan Zhang (2000) menunjukkan adanya perbedaan yang signifikan pada pembingkaian pesan, subjek yang menerima pembingkaian pesan positif mempunyai sikap terhadap produk yang lebih besar daripada subjek yang menerima pembingkaian pesan negatif. 


\section{Euis Soliha}

\section{H. Sophiyanto Wuryan \\ R. Basiya}

Ketika pemasar menyampaikan pesan, pembingkaian pesan perlu menjadi perhatian. Pembingkaian pesan ini kemungkinan akan berpengaruh terhadap persepsi konsumen pada suatu iklan

Berdasarkan uraian di atas dapat dirumuskan hipotesis kesatu sebagai berikut H1: Terdapat perbedaan persepsi risiko psikologis yang dirasakan konsumen pada iklan dengan menggunakan pembingkaian pesan positif dan negatif.

\section{Consumer Product Knowledge/Pengetahuan Konsumen}

Pengetahuan konsumen terdiri atas dua komponen yaitu: familiarity dan expertise (Jacoby, 1986 seperti dikutip Biswas, et al., 2006). Familiarity didefinisikan sebagai sejumlah produk yang berhubungan dengan pengalaman konsumen yang terakumulasi. Expertise didefinisikan sebagai kemampuan kinerja produk yang berhubungan dengan kesuksesan tugasnya. Hubungan produk dengan pengalaman ditetapkan pada banyak level meliputi iklan terbuka, pencarian informasi, interaksi dengan salespersons, pilihan dan pengambilan keputusan, pembelian dan penggunaan produk pada berbagai macam situasi. Demikian pula consumer expertise meliputi cognitive structure (seperti kepercayaan terhadap atribut produk) dan cognitive process (keputusan untuk bertindak sesuai keyakinannya) yang diperlukan untuk hubungan kinerja produk dengan kesuksesan tugasnya (Alba dan Hutchinson, 1987). Pengetahuan konsumen berkaitan dengan seluk beluk produk secara khusus.

Sebagai akibat dari pengenalan produk mungkin memberikan konsumen untuk memproses secara efisien informasi-informasi yang ada. Semakin tingginya tingkat pengetahuan konsumen menunjukkan kecenderungan untuk mempelajari secara terperinci terhadap pesan, khususnya untuk produk dengan tehnologi tinggi (Roehm dan Sternthal, 2001 seperti dikutip Biswas, et al., 2006).

Berdasarkan proses internalisasi diusulkan bahwa konsumen yang mempunyai tingkat pengetahuan tinggi tentang produk/jasa, memiliki keyakinan yang lebih tinggi ketika informasi tentang produk disampaikan expert daripada celebrity. Konsumen dengan tingkat pengetahuan yang tinggi mempunyai dasar pengetahuan yang membantu dengan menghubungkan informasi yang memberikan mereka untuk menggunakan pengetahuannya untuk pengambilan keputusan (Cowley dan Mitchell, 2003; Roehm dan Sternthal, 2001 seperti dikutip Biswas, et al., 2006).

Konsumen dengan tingkat pengetahuan rendah mempunyai kepercayaan yang lebih besar pada penggunaan isyarat peripheral sebagai isyarat diagnostic untuk menganalisis risiko yang berhubungan dengan pembelian produk ( Rao dan Monroe, 1988 seperti dikutip Biswas, et al., 2006). Konsumen dengan tingkat pengetahuan rendah mempunyai tingkat keyakinan yang lebih rendah terhadap produk daripada konsumen dengan tingkat pengetahuan yang tinggi. Oleh karena itu tingkat pengetahuan konsumen yang semakin tinggi akan berpengaruh pada keyakinan yang kuat dari beberapa tipe endorser.

Penelitian Biswas, et al., 2006 menunjukkan terdapat perbedaan persepsi risiko yang lebih rendah pada iklan dengan expert endorser daripada celebrity endorser yang semakin diperkuat dengan tingkat pengetahuan konsumen. Dalam penelitian Biswas, et al., 2006 ini persepsi risiko konsumen meliputi persepsi risiko kinerja dan persepsi risiko keuangan.

Tingkat pengetahuan konsumen yang semakin tinggi diduga akan berpengaruh pada keyakinan yang kuat dari bentuk pembingkaian pesan. Woodside dan Singer (1994) dalam Buda dan Zhang (2000) meneliti variabel lain yang mungkin memoderasi pembingkaian pesan. Smith (1996) dalam Buda dan Zhang (2000) menemukan pendidikan konsumen lebih dipengaruhi pembingkaian pesan negatif. Pembingkaian pesan positif mempunyai 
pengaruh lebih baik daripada negatif pada pertimbangan pengambilan keputusan pembelian pada transformasional products (produk yang mudah dibawa dan memberikan manfaat pengalaman pada pengguna).

Berdasarkan uraian dan gambar di atas peneliti merumuskan hipotesis kedua sebagai berikut

H2: Terdapat perbedaan persepsi risiko psikologis yang dirasakan konsumen pada iklan dengan menggunakan pembingkaian pesan positif dan negatif yang semakin diperkuat dengan pengetahuan konsumen.

\section{Model Penelitian}

Model penelitian yang peneliti gunakan dikembangkan dari Grewal, et al. (1994), Buda dan Zhang (2000), Biswas, et al. (2006), dan Soliha dan Zulfa (2009) sebagaimana ditunjukkan dalam gambar 1 .

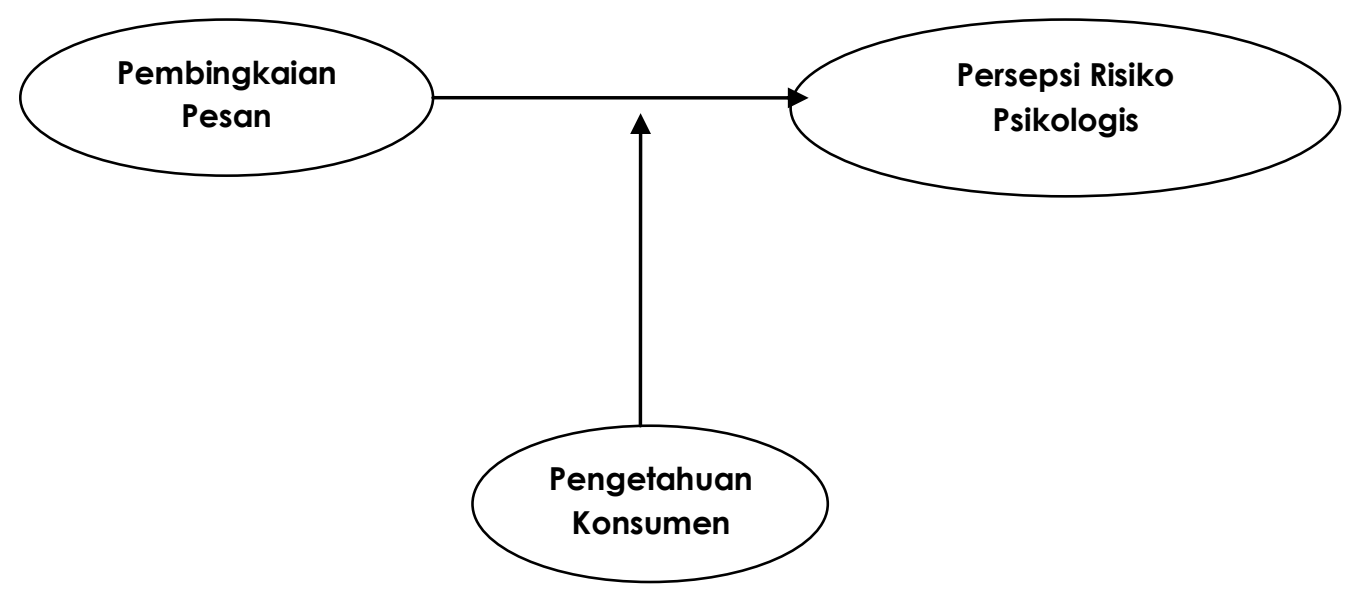

\section{Gambar 1 \\ Model Penelitian Dikembangkan dari Grewal, et al. (1994), Buda dan Zhang (2000), Biswas, et al. (2006), dan Soliha dan Zulfa (2009)}

Berdasarkan model di atas terlihat bahwa persepsi risiko psikologis konsumen sebagai variabel dependen. Sedangkan sebagai variabel independen adalah pembingkaian pesan yang dimanipulasi dalam pembingkaian pesan positif dan negatif. Sedangkan sebagai variabel moderasi adalah tingkat pengetahuan konsumen. Tingkat pengetahuan konsumen diukur dalam tinggi dan rendah.

\section{METODE PENELITIAN}

\section{Strategi Penelitian}

Strategi penelitian yang digunakan oleh peneliti adalah metode eksperimen. Peneliti menggunakan metode eksperimen karena pendekatan riset eksperimen merupakan suatu pendekatan riset yang bertujuan untuk mengidentifikasi hubungan kausal antar variabel. Menurut Christensen (1988: 61) eksperimen merupakan observasi objektif terhadap fenomena yang dibuat untuk terjadi dalam suatu situasi yang sangat terkontrol yang di dalamnya satu atau lebih faktor dibiarkan bervariasi sedangkan faktor-faktor yang lain dipertahankan konstan. Eksperimen adalah suatu studi yang melibatkan keterlibatan peneliti dalam memanipulasi beberapa variabel, mengamati, dan mengobservasi efeknya. Dari definisi ini dapat diketahui bahwa peneliti di eksperimen tidak hanya melakukan 


\section{Euis Soliha}

\section{H. Sophiyanto Wuryan \\ R. Basiya}

pengukuran saja, tetapi juga melakukan intervensi lainnya. Intervensi yang umum dilakukan adalah memanipulasi beberapa variabel, mengamatinya, dan mengobservasi efeknya terhadap subjek yang diteliti. Variabel-variabel yang dimanipulasi atau yang diberi perlakuan adalah variabel-variabel independen dan variabel yang diamati efeknya adalah variabel dependen. Keunggulan eksperimen adalah: validitas internal tinggi, peneliti dapat memanipulasi variabel independen, peneliti dapat mengendalikan pengaruh variabel extraneous, dan bisa direplikasi.

\section{Desain Umum Eksperimen}

Kategori desain eksperimennya adalah eksperimen lab (lab experiments), yakni eksperimen yang dilakukan dalam lingkungan buatan atau diatur (Sekaran dan Bougie, 2010: 228). Desain yang digunakan adalah factorial design yaitu desain yang terdapat dua atau lebih variabel yang dipertimbangkan secara bersamaan (Aaker, et al., 2004: 357-358). Factorial design dalam studi eksperimen ini adalah: $2 \times 1$ between subject. Penelitian dirancang untuk memperoleh data tentang persepsi risiko konsumen terhadap iklan dengan pembingkaian pesan positif dan negatif.

Untuk menguji hipotesis pertama, partisipan dikelompokkan dalam dua kelompok secara acak yang masing-masing diberi perlakuan salah satu dari delapan format iklan yaitu iklan dengan pembingkaian pesan positif dan iklan dengan pembingkaian pesan negatif, dinotasikan sebagai berikut:

\section{1. $E G 1 R \times 1 O 1$ \\ 2. $E G 2 R \times 2 O 2$}

Seorang subjek yang sudah diperlihatkan iklan dengan pembingkaian pesan positif tidak mungkin lagi diperlihatkan iklan dengan pembingkaian pesan negatif karena hal tersebut akan memberikan bias efek urutan (Aaker et al 2004). Oleh karena itu, desain penelitiannya dinotasikan sebagai berikut:

$$
\left.\begin{array}{llll}
\text { 1. } & E G 1 R & (X 1 & O 1) \\
\text { 2. } & E G 2 R & (X 2 & O
\end{array}\right)
$$

Notasi EG1 adalah kelompok eksperimen 1, EG2 adalah kelompok eksperimen 2. R adalah randomisasi (subjek yang ditempatkan secara acak). X1 adalah exposure 1 (subjek yang diperlihatkan perlakuan 1), X2 adalah exposure 2 (subjek yang diperlihatkan perlakuan 2). Ol adalah measurement 1 (respon subjek terhadap perlakuan diukur dengan memberikan kuesioner yang diisi sendiri setelah diberikan perlakuan 1), O2 adalah measurement 2 (respon subjek terhadap perlakuan diukur dengan memberikan kuesioner yang diisi sendiri setelah diberikan perlakuan 2).

Untuk menguji hipotesis ketiga, partisipan dikelompokkan dalam empat kelompok secara acak yang masing-masing diberi perlakuan salah satu dari dua format iklan yaitu iklan dengan pembingkaian pesan positif dan iklan dengan pembingkaian pesan negatif. Peneliti juga mengukur tingkat pengetahuan partisipan dan dikelompokkan dalam tinggi dan rendah. Dinotasikan sebagai berikut:
1. $E G 1 R \quad(X 1 \dagger O 1)$
2. $E G 1 R \quad(x \mid r \quad O 1)$ 


\section{3. $\mathrm{EG} 2 \mathrm{R} \quad(\mathrm{X} 2 \dagger \mathrm{O} 2)$ \\ 4. $\mathrm{EG} 2 \mathrm{R} \quad(\mathrm{X} 2 \mathrm{r} \mathrm{O} 2)$}

\section{Desain Manipulasi}

Pola manipulasi atau perlakuan yang peneliti lakukan berupa iklan cetak yang terdiri dari dua versi yakni (1) iklan dengan pembingkaian pesan positif (iklan versi 1), (2) iklan dengan pembingkaian pesan negatif (iklan versi 2).

\section{Desain Stimuli}

Desain materi stimuli bertujuan untuk mengembangkan kondisi yang mendekati kondisi nyata, sehingga partisipan diharapkan akan memberikan penilaian yang objektif. Materi stimuli berupa iklan yang distimuli dari pembingkaian pesan. Iklan yang digunakan berupa iklan cetak. Iklan cetak dipilih karena dengan menggunakan iklan cetak informasi bisa disampaikan lebih jelas.

Selain menggunakan iklan, materi stimuli yang lain adalah kuesioner yang akan digunakan untuk mengetahui bagaimana persepsi risiko yang dirasakan konsumen pada iklan dengan menggunakan pembingkaian pesan yang berbeda.

\section{Partisipan Penelitian}

Dalam penelitian ini partisipan yang dipilih adalah orang dewasa. Menurut Assael (2001) berdasarkan karakteristik demografi konsumen dewasa adalah konsumen berusia di atas 20 tahun. Partisipan dipilih secara sukarela. Dalam pemilihan kelompok-kelompok eksperimen dengan randomisasi penugasan. Randomisasi yaitu suatu teknik kontrol yang menyamakan kelompok-kelompok subjek eksperimen dengan cara menjamin setiap subjek mempunyai kesempatan yang sama untuk ditempatkan pada kelompok manapun (Christensen 1988: 174). Randomisasi digunakan untuk meminimalkan atau bahkan menghilangkan pengaruh dari variabel ekstrani.

\section{HASIL PENELITIAN DAN PEMBAHASAN}

\section{Homogenitas}

Pengujian homogenitas dilakukan terhadap variabel kontrol yaitu jenis kelamin, penghasilan, umur, dan pekerjaan. Pengujian homogenitas dilakukan untuk melihat apakah terdapat variabel kontrol yang berperan sebagai variabel moderasi. Apabila hasil uji homogenitas menunjukkan signifikansi sebesar di bawah 0,05 maka ada kemungkinan peran variabel kontrol sebagai variabel moderasi. Sedangkan apabila hasil uji homogenitas menunjukkan signifikansi sebesar di atas 0,05 maka variabel kontrol tidak berperan sebagai variabel moderasi. Hasil uji homogenitas menunjukkan bahwa variabel jenis kelamin, penghasilan, umur, dan pekerjaan menghasilkan pengujian yang homogen yang ditunjukkan dengan signifikansi sebesar di atas 0,05 sehingga semua variabel jenis kelamin, umur, pekerjaan, dan penghasilan tidak berperan sebagai variabel moderasi.

Tabel 1

Hasil Uji Homogenitas

\begin{tabular}{|c|}
\hline Pearson Chi-Square \\
\hline
\end{tabular}




\section{Euis Soliha}

\section{H. Sophiyanto Wuryan}

R. Basiya

\begin{tabular}{|l|c|c|c|}
\hline $\begin{array}{l}\text { Jenis } \\
\text { Kelamin }\end{array}$ & 0,000 & 1 & Homogen \\
\hline Penghasilan & 1,456 & 0,483 & Homogen \\
\hline Umur & 2,449 & 0,485 & Homogen \\
\hline Pekerjaan & 1,446 & 0,695 & Homogen \\
\hline
\end{tabular}

Sumber: diambil dari Lampiran (2013)

\section{Validitas dan Reliabilitas}

Pengujian validitas dilakukan dengan analisis faktor. Analisis faktor digunakan untuk menguji validitas konvergensi dan diskriminan. Item pengukuran dapat dianggap memenuhi validitas konvergensi apabila item tersebut memiliki bobot faktor lebih dari 0,30 pada faktor yang sesuai dengan definisi konseptualnya dan memiliki bobot faktor yang rendah pada faktor lain yang tidak sesuai dengan definisi konseptualnya (Hair et al., 2006). Hasil analisis faktor ditunjukkan pada Tabel 2.

Tabel 2

Hasil Analisis Faktor Risiko Psikologis dan Risiko Sosial

\begin{tabular}{|l|c|c|}
\hline & Komponen \\
\hline & $\mathbf{1}$ & $\mathbf{2}$ \\
\hline Risiko Psikologis1 & 0,927 & 0,030 \\
\hline Risiko Psikologis2 & 0,929 & $-0,115$ \\
\hline Risiko Psikologis3 & 0,845 & $-0,013$ \\
\hline CPK1 & 0,084 & 0,917 \\
\hline CPK2 & $-0,179$ & 0,589 \\
\hline CPK3 & 0,043 & 0,936 \\
\hline
\end{tabular}

Sumber: diambil dari Lampiran (2013)

Hasil uji reliabilitas menunjukkan bahwa semua variabel telah memenuhi uji reliabilitas. Cronbach's Alpha harus lebih besar dari 0,60 dan Corrected Item-Total Correlation di atas 0,5 (Hair et al, 2006). Item-item dengan Item-Total Correlation kurang dari 0,5 dipertahankan jika eliminasi item-item tersebut menghasilkan Cronbach's Alpha lebih rendah (Boorom et al, 1998; Hair et al, 1998 dalam Purwanto, 2003).

Tabel 3

Hasil Uji Reliabilitas

\begin{tabular}{|l|c|}
\hline Variabel & Cronbach's Alpha \\
\hline Risiko Psikologis & 0,889 \\
\hline CPK & 0,743 \\
\hline
\end{tabular}

Sumber: diambil dari Lampiran (2013)

\section{Analisis Data}

Metode analisis yang digunakan untuk menguji hipotesis 1 adalah menggunakan one way anova, sedangkan untuk menguji hipotesis 2 digunakan two ways anova dengan main effect dan interraction effect.

\section{Pengujian Hipotesis 1}

Hipotesis 1 menyatakan bahwa terdapat perbedaan persepsi risiko psikologis yang dirasakan konsumen pada iklan dengan menggunakan pembingkaian positif dan negatif. 
Pengujian dengan Anova dengan variabel dependen risiko psikologis menunjukkan bahwa pembingkaian pesan dalam iklan memiliki pengaruh pada persepsi risiko psikologis ( $\mathrm{F}=$ $175,233 ; p=0,000<0,05)$. Pembingkaian pesan positif dalam iklan akan menghasilkan persepsi risiko psikologis yang lebih rendah daripada persepsi risiko psikologis dengan pembingkaian pesan negatif dalam iklan. Tabel 4 merangkum statistik pengujian terhadap hipotesis 1.

Tabel 4

Hasil Anova Perbedaan Persepsi Risiko Produk Berdasar Pembingkaian Pesan Positif dan Negatif

\begin{tabular}{|l|c|c|c|c|c|c|}
\hline $\begin{array}{l}\text { Variabel } \\
\text { Dependen }\end{array}$ & $\begin{array}{c}\text { Pembing-kaian } \\
\text { Pesan Positif }\end{array}$ & $\begin{array}{c}\text { Jumlah } \\
\text { Partisipan }\end{array}$ & $\begin{array}{c}\text { Pembingkaian } \\
\text { Pesan Negatif }\end{array}$ & $\begin{array}{c}\text { Jumlah } \\
\text { Partisipan }\end{array}$ & $\begin{array}{c}\mathbf{F} \\
\text { Statistik }\end{array}$ & $\begin{array}{c}\text { Nilai } \\
\mathbf{P}\end{array}$ \\
\hline $\begin{array}{l}\text { Risiko } \\
\text { Psikologis }\end{array}$ & 2,5889 & 30 & 4,5889 & 30 & 175,233 & 0,00 \\
\hline
\end{tabular}

Sumber: diambil dari Lampiran (2013)

\section{Pengujian Hipotesis 2}

Hipotesis 2 menyatakan bahwa terdapat perbedaan persepsi risiko yang dirasakan konsumen pada iklan dengan menggunakan pembingkaian pesan positif dan negatif yang semakin diperkuat dengan pengetahuan konsumen.

Pengujian dengan two ways anova dengan variabel dependen risiko psikologis menunjukkan bahwa pembingkaian pesan dalam iklan dan pengetahuan konsumen tidak memiliki pengaruh pada persepsi risiko psikologis $(F=0,080 ; p=0,778>0,05)$. Tabel 5 merangkum statistik pengujian terhadap hipotesis 2.

\section{Tabel 5}

Hasil Anova Perbedaan Persepsi Risiko Produk Berdasar Pembingkaian Pesan Positif dan Negatif dan Motivasi Rasional dan Emosional

\begin{tabular}{|c|c|c|c|c|c|c|c|c|}
\hline $\begin{array}{l}\text { Variabel } \\
\text { Dependen }\end{array}$ & $\begin{array}{l}\text { Pembing } \\
\text { Pesan Po }\end{array}$ & $\begin{array}{l}\text { aian } \\
\text { itiff }\end{array}$ & $\begin{array}{l}\text { Jumlah } \\
\text { Partisipan }\end{array}$ & $\begin{array}{l}\text { Pembing } \\
\text { Pesan N }\end{array}$ & $\begin{array}{l}\text { kaian } \\
\text { gatif }\end{array}$ & $\begin{array}{l}\text { Jumlah } \\
\text { Partisipan }\end{array}$ & $\begin{array}{l}\mathbf{F} \\
\text { Statistik }\end{array}$ & Nilai $P$ \\
\hline $\begin{array}{l}\text { Risiko } \\
\text { Psikologis }\end{array}$ & $\begin{array}{l}\text { CPK } \\
\text { Rendah } \\
\text { CPK } \\
\text { Tinggi }\end{array}$ & $\begin{array}{l}2,6154 \\
2,5686\end{array}$ & $\begin{array}{l}13 \\
17\end{array}$ & $\begin{array}{l}\text { CPK } \\
\text { Rendah } \\
\text { CPK } \\
\text { Tinggi }\end{array}$ & $\begin{array}{l}4,6471 \\
4,5128\end{array}$ & $\begin{array}{l}17 \\
13\end{array}$ & 0,080 & 0,778 \\
\hline
\end{tabular}

Sumber: diambil dari Lampiran (2013)

\section{Pembahasan}

Hasil pengujian terhadap hipotesis 1 dengan variabel dependen persepsi risiko psikologis menunjukkan hasil yang signifikan. Hal ini menunjukkan bahwa terdapat perbedaan persepsi risiko psikologis pada iklan dengan menggunakan pembingkaian pesan positif dan pembingkaian pesan negatif. Konsumen merasakan persepsi risiko psikologis yang lebih rendah pada iklan dengan pembingkaian pesan positif. Pada iklan dengan pembingkaian positif konsumen akan merasa ikut menjaga lingkungan sehingga konsumen akan merasakan persepsi risiko yang lebih rendah. Hasil penelitian ini sesuai dengan penelitian Fatmawati (2012) yang menunjukkan keunggulan pembingkaian pesan positif dibanding pembingkaian pesan negatif pada perceived scarcity, Soliha dan Purwanto (2012) yang meneliti pada iklan perguruan tinggi yang menunjukkan bahwa pembingkaian pesan negatif dalam iklan cenderung menghasilkan persepsi risiko kinerja, risiko keuangan, risiko sosial, dan risiko psikologis yang lebih tinggi daripada persepsi risiko yang dihasilkan oleh 


\section{Euis Soliha}

\section{H. Sophiyanto Wuryan \\ R. Basiya}

pembingkaian pesan positif. Konsumen merasakan persepsi risiko kinerja, risiko keuangan, risiko sosial, risiko psikologis yang lebih rendah pada iklan dengan pembingkaian pesan positif daripada pembingkaian pesan negatif. Buda dan Zhang (2000) yang meneliti pada iklan produk elektronik, Grewal, et al.(1994) yang meneliti pada iklan produk elektronik, serta Levin dan Gaeth (1988) yang meneliti pada iklan daging. Semua penelitian tersebut menunjukkan bahwa pembingkaian pesan positif lebih efektif daripada pembingkaian pesan negatif. Jadi, dapat disimpulkan bahwa pada iklan isu konsumen hijau lebih efektif digunakan pembingkaian pesan positif.

Hasil pengujian terhadap hipotesis 2 menunjukkan hasil yang tidak signifikan. Hal ini menunjukkan bahwa tidak terdapat perbedaan persepsi risiko psikologis yang dirasakan konsumen pada iklan dengan menggunakan pembingkaian pesan positif dan pembingkaian pesan negatif yang semakin diperkuat dengan pengetahuan konsumen. Pengetahuan konsumen ternyata tidak memoderasi pengaruh pembingkaian pesan pada persepsi risiko konsumen. ELM mengidentifikasi tingkat pengetahuan seseorang untuk memproses argumentasi-argumentasi pesan yang bersifat sentral sebagai salah satu faktor kunci yang memengaruhi dampak relatif dari pemrosesan sentral dan bukan sentral. Hasil penelitian ini sesuai dengan penelitian Soliha dan Zulfa (2009) yang menunjukkan bahwa tidak terdapat perbedaan yang signifikan pada persepsi risiko yang dirasakan konsumen pada iklan perguruan tinggi dengan menggunakan pembingkaian pesan positif dan pembingkaian pesan negatif yang semakin diperkuat dengan pengetahuan konsumen. Pada iklan isu konsumen hijau pengaruh pembingkaian pesan pada persepsi risiko tidak dimoderasi oleh pengetahuan konsumen. Hal ini terjadi karena produk dalam isu konsumen hijau ini merupakan produk dengan keterlibatan tinggi, sehingga dalam memproses pesan konsumen akan memfokuskan pemrosesan informasi pada hal-hal yang sentral dan detilnya. Pemrosesan secara sentral ini terjadi ketika penerima pesan mempunyai motivasi dan kemampuan untuk berpikir mengenai pesan dan topiknya. Jadi dalam hal ini pengetahuan konsumen tentang produk tidak memoderasi pengaruh pembingkaian pesan pada persepsi risiko konsumen.

\section{KESIMPULAN}

\section{Simpulan}

Dari hasil analisis dan pembahasan dalam Bab IV di muka, maka dapat disimpulkan sebagai berikut.

Terdapat perbedaan yang signifikan pada persepsi risiko pada iklan dengan menggunakan pembingkaian pesan positif dan pembingkaian pesan negatif. Konsumen merasakan persepsi risiko psikologis yang lebih rendah pada iklan dengan pembingkaian pesan positif. Jadi pada iklan produk yang terkait dengan isu konsumen hijau akan lebih efektif dengan menggunakan pembingkaian pesan positif.

Hasil pengujian hipotesis 2 menunjukkan tidak terdapat perbedaan yang signifikan pada persepsi risiko pada iklan dengan menggunakan pembingkaian pesan positif dan pembingkaian pesan negatif yang semakin diperkuat dengan pengetahuan konsumen. Pengetahuan konsumen ternyata tidak memoderasi pengaruh pembingkaian pesan pada persepsi risiko psikologis konsumen.

\section{Keterbatasan Penelitian dan Saran}

Penelitian ini mempunyai beberapa keterbatasan. Pertama, desain eksperimen laboratorium yang peneliti gunakan dalam penelitian ini mungkin menyebabkan lemahnya naturalitas dalam penelitian tetapi dapat mencapai validitas internal yang tinggi, sehingga untuk penelitian yang akan datang bisa melengkapi dengan desain survei. Kedua, pengetahuan 


\section{Jurnal Manajemen Teori dan Terapan \\ Tahun 6. No. 2, Agustus 2013}

konsumen sebagai variabel pemoderasi ternyata tidak memoderasi pengaruh pembingkaian pesan pada persepsi risiko psikologis konsumen. Untuk penelitian yang akan datang hendaknya dikembangkan kembali pengukuran yang lebih komprehensif terkait dengan pengukuran tingkat pengetahuan konsumen.

\section{Implikasi Pemasaran}

Secara praktis hasil penelitian ini dapat diaplikasikan untuk meningkatkan efektivitas suatu iklan. Khususnya bagi pemasar produk terkait isu konsumen hijau, hasil ini dapat dijadikan acuan dalam pengambilan keputusan tentang penggunaan pembingkaian pesan yang efektif. Pada iklan isu konsumen hijau dapat menggunakan pembingkaian pesan positif dalam periklanan karena terbukti dengan menggunakan pembingkaian pesan positif, persepsi risiko konsumen yang dirasakan semakin kecil.

\section{DAFTAR REFERENSI}

Aaker, D.A; V. Kumar; and G.S. Day (2004), Marketing Research, $8^{\text {th }}$ ed. New York: John Wiley \& Sons, Inc.

Alba, Joseph W. and J. W. Hutchinson (1987), "Dimensions of Consumer Expertise," Journal of Consumer Research, 13 (March), pp. 411-454.

Assael, H (2001), Consumer Behavior and Marketing Action, $7^{\text {th }}$ ed. Singapore: Thomson Learning.

Atkin, Charles and M. Block (1983), "Effectiveness of Celebrity Endorsers," Journal of Advertising Research, 23 (February/March), pp. 57-61.

Biswas, Dipayan; A. Biswas; and N. Das (2006), "The Differential Effects of Celebrity and Expert Endorsements on Consumer Risk Perceptions," Journal of Advertising, 35 (Summer), pp. 17-31.

Buda, Richard and Y. Zhang (2000), "Consumer Product Evaluation: The Interactive Effect of Message Framing, Presentation Order, and Source Credibility," Journal of Product and Brand Management, Vol.9, No.4, pp. 229-242.

Christensen, B, Larry (1988), Experimental Methodology, $4^{\text {th }}$ ed. Boston: Allyn and Bacon, Inc.

Cox, Donald F and S. J. Rich (1964), "Perceived Risk and Consumer Decision Making," Journal of Marketing Research, 1 (November), pp. 32-39.

Crask, M; R.J.Fox; and R.G.Stout (1995), Marketing Research: Principles and Applications, Englewood Cliffs, NJ: Prentice-Hall.

Dharmmesta, Basu Swastha (1997), Segi-segi Penulisan Karya IImiah, Magister Manajemen, UGM, Yogyakarta.

Dowling, Grahame R. and R. Staelin (1994), "A Model of Perceived Risk and Intended RiskHandling Activity," Journal of Consumer Research, 21 (June), pp. 119-134.

Fatmawati, Indah (2012), "Pengaruh Pembingkaian Pesan, Informasi Kelangkaan, dan Perbedaan Individual pada Sikap, Niat, dan Perilaku Hemat Energi Listrik," Disertasi Strata 3 Program Doktor IImu Manajemen, Fakultas Ekonomika dan Bisnis, Universitas Gadjah Mada, Yogyakarta (tidak dipublikasikan).

Friedman, Hershey H. and L. Friedman (1979), "Endorser Effectiveness by Product Type," Journal of Advertising Research, 19 (October), pp 63-71.

Ganzach, Y and N. Karsahi (1995), "Message Framing and Buying Behavior: A Field Experiment," Journal of Business Research, 32, pp. 11-17.

Ghozali, Imam. 2006. Aplikasi Analisis Multivariat dengan Program SPSS. Badan Penerbit Universitas Diponegoro. Semarang.

Grewal, Dhruv; J. Gotlieb; and H. Marmorstein (1994), "The Moderating Effects of Message Framing and Source Credibility on the Price-Perceived Risk Relationship," Journal of Consumer Research, 21 (June), pp. 145-153.

Hair, Jr; Joseph F; W. C Black; B. J. Babin; R. E. Anderson; and R. L. Tatham. (2006), Data Analysis Multivariate, $6^{\text {th }}$ ed. Upper Saddle River. NJ: Pearson Education, Inc. 


\section{Euis Soliha}

\section{H. Sophiyanto Wuryan}

\section{R. Basiya}

Hair, Jr, Joseph F; W. C Black; B. J. Babin; and R. E. Anderson (2010), Multivariate, $7^{\text {th }}$ ed. Upper Saddle River, NJ: Pearson Education, Inc.

Kotler, P. and K.L.Keller (2009), Marketing Management, 13 th ed. Upper Saddle River, NJ: Pearson Education, Inc.

Lavidge, Robert J and G. A. Steiner, "A Model for Predictive Measurements of Advertising Effectiveness" in B.M. Enis; K.K. Cox; and M.P. Mokwa, Marketing Classic: A Selection of Influential Articles, $8^{\text {th }}$ ed. London, Allyn and Bacon, pp. 523-527.

Levin, L. and G.J. Gaeth (1988), "How Consumer are Affected by the Framing of Attribute Information before and after Consuming the Product," Journal of Consumer Research, 15, pp. 374-378.

Maheswaran, D. and J. Meyers-Levy (1990), "The Influence of Message Framing and Issue Involvement," Journal of Marketing Research, 27, pp.361-367.

Meyerowitz, B. E. and S. Chaiken (1987), "The Effect of Message Framing on Breast SelfExamination Attitudes, Intentions, and Behavior," Journal of Personality and Social Psychology, Vol. 52, No. 3, pp. 500-510.

Neuman, W. Lawrence (2003), Social Research Methods: Qualitative and Quantitative Approaches, $5^{\text {th }}$ ed. London: Allyn and Bacon.

Park, C.Whan; D. L. Mothersbaugh; and L. Feick (1994), "Consumer Knowledge Assessment," Journal of Consumer Research, 21 (June), pp 71-82.

Purwanto, BM. 2003, "Does Gender Moderate the Effect of Role Stress on Salesperson' Internal States and Performance?" Buletin Ekonomi UPN "Veteran" Yogyakarta, 6 (Agustus), hal. 1-20.

Rothman, A.J. and P. Salovey (1997), "Shaping Perceptions to Motivate Healthy Behavior: the Role of Message Framing, Psychological Bulletin, 121, pp. 3-19.

Shimp, Terence A. and W. O. Bearden (1982), "Warranty and Other Extrinsic Cue Effects on Consumers' Risk Perceptions," Journal of Consumer Research, 9 (June), pp 38-46.

Smith, G.E. (1996), Framing in Advertising and the Moderating Impact of Consumer Education," Journal of Advertising Research, 36, pp. 49-64.

Soliha, Euis (2007), "Perbedaan Persepsi Risiko Konsumen antara Iklan dengan Menggunakan Celebrity Endorser dan Expert Endorser," Thesis Strata 2 Magister Sains (MSi), Fakultas Ekonomika dan Bisnis, Universitas Gadjah Mada, Yogyakarta (tidak dipublikasikan).

Soliha, Euis (2011), "Pengaruh Kredibilitas Sumber dan Kerangka Pesan pada Persepsi resiko Konsumen, Jurnal Manajemen Teori dan Terapan, Universitas Airlangga, Surabaya, Tahun 4, No. 3, Hal.13-23.

Soliha, Euis (2013), "Pengaruh Pembingkaian Pesan dan Kredibilitas Sumber pada Persepsi Risiko Konsumen dengan Motivasi dan Need for Cognition sebagai Pemoderasi, Disertasi Strata 3 Program Doktor IImu Manajemen, Fakultas Ekonomika dan Bisnis, Universitas Gadjah Mada, Yogyakarta (tidak dipublikasikan).

Soliha, Euis dan BM. Purwanto (2012), "Pengaruh Pererangkaan Pesan pada Persepsi Risiko Konsumen dengan Motivasi sebagai Variabel Pemoderasi," Jurnal Siasat Bisnis, Vol. 16 (1).

Soliha, Euis and B.S. Dharmmesta (2012), "The Effect of Source Credibility and Message Framing on Consumer Risk Perceptions with Consumer Prodiuct Knowledge as A Moderating Variable: A Literature Review," International Research Journal, Educational Research, Vol. 3(2), pp. 108-117.

Soliha, Euis; B.S. Dharmmesta; BM. Purwanto; and S.P. Syahlani (2012), "Message Framing and Source Credibility in Functional Food Advertisements," Proceeding in The 2nd International Business Management Research Conference, Faculty of Business Administration, Chiang Mai University, Thailand, 16 th November 2012.

Soliha, Euis and N. Zulfa (2009), "The Difference in Consumer Risk Perception between Celebrity Endorser and Expert Endorser in College Advertisements," Journal of Indonesian Economy \& Business, Vol.24, No.1, January, pp. 100-114.

Stone, Robert N. and K. Gronhaug (1993), "Perceived Risk: Further Considerations for the Marketing Discipline," European Journal of Marketing, Vol.27, No.3, pp 39-50. 